\title{
Meningkatkan Keterampilan Menulis Teks dengan Penggabungan Metode Pembelajaran Berbasis Teks dan Kerja Kelompok
}

\author{
Veronika Napitu ${ }^{*}$ \\ ${ }^{1}$ Pendidikan Bahasa Inggris, Universitas Pendidikan Ganesha, Singaraja, Indonesia
}

\section{ART I C L E I N F O}

Article history:

Received June 16, 2021

Revised June 18, 2021

Accepted September 20, 2021

Available online November 25, 2021

Kata Kunci:

Metode Pembelajaran Berbasis Teks, Menulis Teks Prosedur

\section{Keywords:}

Text-Based Learning Method, Writing Procedure Text

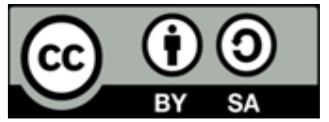

This is an open access article under the CC BY-SA license.

Copyright (c) 2021 by Author. Published by Universitas Pendidikan Ganesha.

\begin{abstract}
A B S T R A K
Keterampilan menulis teks merupakan salah satu keterampilan yang wajib dikuasai oleh siswa dalam mata pelajaran Bahasa Inggris. Hanya saja pada kenyataannya, tidak semua siswa mampu menulis dengan baik karena kurangnya pelatihan yang diberikan oleh guru. Penelitian ini bertujuan menganalisis penggunaan metode pembelajaran berbasis teks dan kerja kelompok terhadap keterampilan menulis teks pada peserta didik. Penelitian ini adalah penelitian tindakan kelas yang dilaksanakan dalam dua siklus. Subjek penelitian ini adalah siswa kelas IX Sekolah Menengah Pertama, dengan jumlah siswa sebanyak 35 orang. Pengumpulan data dalam penelitian dilakukan dengan menggunakan metode tes dan metode kuesioner. Hasil penelitian menunjukkan bahwa penggunaan metode pembelajaran berbasis teks dan kerja kelompok dapat meningkatkan kemampuan menulis teks peserta didik. Skor rata-rata keterampilan menulis teks prosedur pada siklus I sebesar 71,66 dengan ketuntasan klasikal sebesar $45,71 \%$. Terjadi peningkatan pada siklus II dengan rata-rata nilai peserta didik 78,86 dengan ketuntasan klasikal sebesar $77,14 \%$. Respon peserta didik pada siklus I 40,11 dengan kategori positif, sedangkan pada saat siklus II naik menjadi 43,74 pada siklus II dengan kategori positif. Jadi, terjadi peningkatan keterampilan menulis teks prosedur siswa setelah dilakukan pembelajaran dengan menggunakan metode pembelajaran berbasis teks dan kerja kelompok.
\end{abstract}

\section{A B S T R A C T}

Text writing is one of the skills that students in English must master. It is just that, in reality, not all students can write well because of the lack of training provided by the teacher. This study aims to analyze text-based learning methods and group work on students' text writing skills. This research is classroom action research which is conducted in two cycles. The subjects of this study were students of class IX of Junior High School, with 35 students. Data collection in the study was carried out using the test method and the questionnaire method. The results showed that text-based learning methods and group work could improve students' text writing skills. The first cycle's average score of procedural text writing skills was 71.66 , with classical completeness of $45.71 \%$. There was an increase in cycle II. The average value of students was 78.86 , with classical completeness of $77.14 \%$. Students' response in the first cycle was 40.11 with a suitable category, while it rose to 43.74 in the second cycle with a positive category. So, there was an increase in students' procedural text writing skills after learning using text-based learning methods and group work.

\section{PENDAHULUAN}

Keterampilan menulis teks dalam pembelajaran Bahasa Inggris menjadi sangat krusial, terutama di setiap tingkat pendidikan di Indonesia karena penggunaan bahasa tersebut sebagai bahasa asing atau kedua, setelah Bahasa Indonesia (Faiza \& Erowati, 2021; Munggaraning \& Westhisi, 2019). Dalam pembelajaran Bahasa Inggris, peserta didik dikatakan memiliki kemampuan menulis teks yang baik jika mampu menggunakan Bahasa Inggris tersebut dalam tulisan yang sesuai dengan kaidah penulisan, konteks, dan topik yang ditentukan (Engliana et al., 2020; Koswara, 2021; Ratnawati, 2020). Pengusaan 
terhadap berbagai unsur kebahasaan menjadi salah satu keharusan dalam proses menulis (Mabruri, 2021). Hal ini menunjukkan bahwa pada pembelajaran menulis, ada beberapa aspek yang perlu diperhatikan, seperti ide, tata bahasa, kosakata, serta penggunaan tanda baca. Selain itu, perlu juga pengetahuan tentang konteks suatu ide yang hendak ditulis agar tulisan itu lebih menarik dan mudah dipahami. Keterampilan menulis menjadi salah satu kompetensi dasar yang harus dicapai oleh setiap peserta didik sesuai dengan Silabus K-13 mata pelajaran Bahasa Inggris (Ati et al., 2018). Komptensi menulis yang harus dikuasai terdiri dari keterampilan menyusun teks prosedur, lisan dan tulis, pendek dan sederhana, berbentuk resep dan manual, dengan meperhatikan fungsi sosial, struktur teks, dan unsur kebahasaan yang benar dan sesuai konteks (Suryani, 2021; Utami, 2021). Teks prosedur adalah teks yang berisi langkah-langkah atau tahapan yang harus ditempuh untuk mencapai tujuan (Devi, 2018; Utama, 2019). Untuk mencapai tujuan yang tepat, teks prosedur harus disusun sesuai urutan yang benar. Maka sudah jelas bahwa tujuan pembelajaran menulis adalah mengharapkan peserta didik untuk bisa menulis teks prosedur, baik dalam bentuk resep maupun manual, dengan langkah-langkah yang berurutan sesuai dengan unsur kebahasaan yang digunakan dalam teks tersebut serta konteks atau topik yang diminta (Musa, 2019; Soleh, 2021; Trisnadewi et al., 2020). Untuk unsur kebahasaan yang dipakai dalam teks prosedur adalah seperti bentuk kalimat perintah, kata kerja bentuk pertama, kata keterangan penghubung, kata keterangan cara, dan kosakata terkait (Sobandi, 2020; Sulistyowati, 2018). Sedangkan konteks atau topik yang digunakan dalam teks prosedur mengacu pada bentuk teks yang diminta (resep atau manual) yang nantinya konteks atau topik ini akan memengaruhi unsur kebahasaan yang dipakai.

Dalam pembelajaran Bahasa Inggris, terdapat KKM yang harus dipenuhi peserta didik sebagai indikator tercapainya kompetensi dasar tersebut. Hanya saja kenyataan di lapangan menunjukkan bahwa sebagian besar siswa masih belum mampu mencapai nilai KKM pada keterampilan menulis dalam bahasa Inggris. Hal ini sejalan dengan hasil observasi yang telah dilakukan di kelas IX 9 SMP Negeri 2 Singaraja. Hasil observasi menunjukkan bahwa kemampuan menulis peserta didik terhadap teks prosedur sangat rendah, yaitu 22,31. Dari data awal yang diperoleh dapat juga diketahui bahwa hanya 1 orang yang masuk pada kategori tuntas dengan nilai 75. Rendahnya kemampuan menulis siswa dapat disebabkan oleh kurangnya minat siswa dalam hal menulis (Hikmatin, 2020; Kiuk et al., 2021). Jika dibiarkan secara terus menerus hal ini akan berdampak pada rendahnya kemampuan serta kompetensi siswa dalam mata pelajaran Bahasa Inggris. Untuk mengatasi masalah tersebut, maka dibutuhkan suatu metode pembelajaran yang tepat serta dapat menunjang proses pembelajaran siswa. Salah satu metode yang dapat digunakan untuk meningkatkan keterampilan menulis siswa, yakni metode pembelajaran berbasis teks yang berpatokan pada teori lingustik sistemik fungsional (LSF). Teks pada dasarnya merupakan satuan bahasa dalam bentuk tulisan atau lisan yang tersusun secara terstruktur dan memiliki makna serta konteks/genre tertentu (Darlan et al., 2021; Dewantara et al., 2019; Rustini, 2021). Genre merupakan proses sosial yang berorientasi kepada tujuan yang dicapai secara bertahap. Jadi, pembelajaran bahasa dapat dilakukan melalui teks. Di dalam sebuah teks tersebut terdapat suatu situasi sosial maupun nilainilai budaya yang tergambar melalui bentuk-betuk bahasa yang digunakan. Sintak pembelajaran dalam metode pembelajaran berbasis teks terdiri dari empat tahap, yaitu building knowledge of text, modelling the text, joint construction of text, dan independent construction of text, namun, istilah yang dipakai di dalam penelitian ini adalah building knowledge of text, modelling the text, deconstructing the text, dan joint construction of text (Estrini, 2021; Rahma et al., 2018).

Pelaksanaan metode pembelajaran berbasis teks dapat dikombinasikan dengan teknik kerja kelompok. Hal ini masih sejalan dengan sintak pembelajaran yang ada pada metode ini, dimana guru membimbing peserta didik memproduksi teks melalui proses pemberian bantuan (scaffolding). Pada tahap building the knowledge dan modelling the text, kapasitas guru dalam memberikan bantuan masih besar, namun secara bertahap akan dikurangi (Narasintawati et al., 2020). Pada tahap joint construction the text, peserta didik sudah mulai bekerja dalam kelompok dan bimbingan guru sudah mulai berkurang, namun tetap memberikan feedback atas kerja peserta didik dalam kelompok (Estrini, 2021). Pada tahap inilah teknik kerja kelompok diterapkan. Teknik kerja kelompok adalah format belajar-mengajar yang menitikberatkan kepada interaksi antar anggota dalam suatu kelompok belajar guna menyelesaikan tugas-tugas secara bersama-sama (Puwerman, 2021). Kerja kelompok dikakukan karena situasi kelas yang heterogen, baik dari segi kemampuan dan motivasi (Sijabat \& Dinar, 2019; Uddin \& Oktaviarini, 2019). Dengan memerhatikan prinsip metode pembelajaran berbasis teks, peserta didik dapat mempelajari dengan baik cara menulis teks dan sekaligus mempelajari bahasa melalui konteks yang terdapat dalam teks tersebut.

Beberapa penelitian yang telah dilakukan sebelumnya menyebutkan bahwa terdapat peningkatan keaktifan dan hasil belajar peserta didik pada mata pelajaran Bahasa Inggris melalui penerapan model pembelajaran berbasis teks (Rustini, 2021). Hasil penelitian lainnya juga menyebutkan bahwa metode pembelajaran berbasis teks sangat efektif digunakan dalam pembelajaran Bahasa Indonesia. Melalui 
metode pembelajaran berbasis teks, siswa dapat dengan mudah memahami serta merancang suatu karya tulis (Dewantara et al., 2019). Penelitian selanjutnya mengungkapkan bahwa metode kerja kelompok mampu meningkatkan motivasi belajar siswa. Proses pembelajaran dengan menggunakan metode kerja kelompok mampu menciptakan suasana belajar yang menyenangkan serta tidak membuat jenuh siswa (Papasi, 2020). Berdasarkan hasil penelitian tersebut dapat dikatakan bahwa penggunaan metode pembelajaran berbasis teks secara signifikan mampu meningkatkan kemampuan siswa dalam mata pelajaran bahasa Indonesia maupun bahasa Inggris. Selain metode berbasis teks penggunaan metode kerja kelompok juga mampu menciptakan suasana pembelajaran yang menyenangkan bagi siswa, sehingga siswa lebih mudah memahami materi yang disampaikan. Hanya saja pada penelitian sebelumnya, belum terdapat kajian yang menggabungkan penggunaan metode pembelajaran berbasis teks dan kerja kelompok untuk meningkatkan keterampilan menulis siswa. Oleh karena itu, penelitian ini difokuskan pada kajian tersebut dengan tujuan untuk mangalisis penggunaan metode pembelajaran berbasis teks dan kerja kelompok dalam meningkatkan keterampilan menulis teks siswa.

\section{METODE}

Penelitian ini merupakan penelitian tindakan kelas yang dilaksanakan dengan memberikan perlakukan terhadap sesuatu, baik itu berupa benda hidup atau mati, serta pengamatan yang ekstensif terhadap reaksi yang ditimbulkan dari pemberian perlakuan tersebut. Penelitian tindakan kelas ini dilakukan dalam 2 siklus penelitian yakni siklus I dan siklus II. Lokasi penelitian adalah SMP Negeri 2 Singaraja dengan subjek penelitian yakni peserta didik kelas IX 9 yang tediri dari 35 orang. Fokus dalam penelitian ini adalah peningkatan kemampuan menulis teks peserta didik setelah diterapkan metode pembelajaran berbasis teks dan kerja kelompok, serta respon peserta didik terhadap penerapan metode tersebut. Data mengenai kemampuan menulis teks prosedur dengan menggunakan metode pembelajaran berbasis teks dan kerja kelompok dikumpulkan dengan metode tes yang diberikan pada akhir pembelajaran, dan respon peserta didik ketika mengikuti pembelajaran menulis teks prosedur melalui penggunaan metode pembelajaran berbasis teks dan kerja kelompok dikumpulkan dengan metode kuesioner. Data yang telah dikumpulkan dianalisis secara deskriptif kualitatif dan deskriptif kuantitatif.

\section{HASIL DAN PEMBAHASAN}

\section{Hasil}

Penelitian mengenai penerapan model pembelajaran berbasis teks dan kerja kelompok untuk meningkatkan kemampuan menulis siswa, diawali dengan tahap prasiklus. Tahap prasiklus dilakukan sebagai acuan pemberian tindakan dalam penelitian selanjutnya. Pada tahap prasiklus peserta didik tidak diberikan pengajaran tentang materi teks prosedur agar nilai tersebut murni dari hasil pemahaman peserta didik sendiri. Hasil pada tahap prasiklus menunjukkan bahwa kemampuan menulis peserta didik terhadap teks prosedur sangat rendah, yaitu 22,31. Dari prasiklus dapat diketahui bahwa hanya 1 orang yang masuk pada kategori tuntas dengan nilai 75 . Berpatokan pada hasil prasiklus, maka dilaksanakan siklus I untuk meningkatkan kemampuan menulis siswa. Tindakan siklus I dilaksanakan selama dua kali pertemuan. Hasil yang diperoleh pada siklus I menunjukkan bahwa rata-rata hasil belajar peserta kelas IX 9 dalam menulis teks prosedur masuk dalam kategori tidak tuntas, yaitu 71,66 karena belum mencapai KKM 75. Meskipun begitu, hasil dari tindakan pada siklus I ini sudah menunjukkan peningkatan jika dibandingkan dengan hasil refleksi awal. Jumlah peserta didik yang tuntas bertambah 15 orang. Adapun persentase peserta didik yang tuntas sebanyak $45,71 \%$ (16 orang) dengan rentang nilai 75 - 85, sedangkan yang tidak tuntas sebanyak 54,29\% (19 orang) dengan rentang nilai 55 - 70. Respon peserta didik terhadap pembelajaran menulis teks prosedur dengan menerapkan metode pembelajaran berbasis teks dan kerja kelompok tergolong kategori positif, yaitu dengan skor rata-rata 40,11. Diketahui bahwa terdapat 1 orang peserta didik dengan respon sangat positif, 31 orang dengan respon positif, dan 3 orang dengan respon cukup positif. Hasil yang diperoleh pada siklus I belum mencapai indikator keberhasilan yang telah ditetapkan sebelumnya, sehingga penelitian dilanjutkan pada pelaksanaan siklus II.

Tindakan pada siklus II tetap menggunakan metode pembelajaran berbasis teks dan kerja kelompok, tetapi pada penyampaian materi menggunakan media video dan potongan gambar. Tindakan siklus II dilaksanakan selama dua kali pertemuan, yaitu pada tanggal 9 - 10 Oktober 2017. Diketahui bahwa rata-rata kelas IX 9 pada materi teks prosedur masuk dalam kategori tuntas, yaitu 78,86 (sudah melewati KKM 75). Hasil tindakan pada siklus II sudah menunjukkan peningkatan yang berarti bila dibandingkan dengan hasil siklus I. Jumlah peserta didik yang tuntas pada siklus II bertambah menjadi 27 orang $(77,14 \%)$ dengan rentang nilai $75-87,5$, meskipun ada 8 orang $(22,86 \%)$ yang masih belum tuntas dengan rentang nilai $70-72,5$. Respon peserta didik terhadap pembelajaran menulis teks prosedur dengan penerapan metode pembelajaran berbasis teks dan kerja kelompok tergolong ke dalam kategori 
positif, yaitu dengan skor rata-rata 43,74 . Diketahui bahwa 7 orang peserta didik dengan persentase $20 \%$ memiliki respon sangat positif, 28 orang peserta didik dengan respon positif dengan persentase $80 \%$, dan tidak ada peserta didik yang memiliki respon cukup positif, kurang positif, dan sangat kurang positif.

\section{Pembahasan}

Hasil analisis penelitian menunjukkan bahwa terdapat peningkatan keterampilan menulis siswa pada siklus I dan II setelah dilaksanakan pembelajaran dengan menggunakan metode berbasis teks dan metode kerja kelompok. Peningkatakan terhadap keterampilan menulis siswa berkaitan dengan tahapantahapan yang dilaksankan dalam metode pembelajaran berbasis teks. Tahap pertama yang dilakukan oleh guru dalam peningkatakan keterampilan menulis siswa yakni membangun pengetahuan siswa mengenai teks (Adeninawaty et al., 2018; Hendrawan \& Indihadi, 2019). Membangun pengetahuan mengenai teks dapat dilakukan dengan mengajak siswa untuk berdiskusi bersama teman sebangku atau dapat juga dilakukan dengan memberikan sedikit pemaparan materi mengenai teks, unsur-unsur teks, serta gaya bahasa yang sebaiknya digunakan dalam teks (Sulissusiawan, 2019). Dalam pembelajaran menulis teks bahasa Inggris siswa harus memperhatikan berbagai unsur-unsur penyusun teks serta tata cara penulisan kalimat dalam bahasa inggris, sehingga pada tahap ini guru harus benar-benar mampu memberikan pemahaman yang baik bagi siswa (Wahyudin et al., 2020).

Tahap pembelajaran kedua yakni dengan modelling the text atau meberikan contoh teks kepada siswa. Pada tahap ini siswa diberikan sebuah contoh teks dalam bahasa Inggris dan mengidentifikasi teks tersebut (Henny \& Fatmasari, 2020; Prakoso et al., 2021). Hal ini dilakukan dengan tujuan agar siswa mampu memahami struktur teks yang baik dan tata cara penulisan teks tersebut. Pada tahap modelling the text, guru dapat mulai membentuk siswa dalam beberapa kelompok, sehingga siswa dapat saling bertukar pikiran dalam mengidentifikasi teks yang telah diberikan. Tahap pembelajaran ketiga yakni deconstructing the text atau merekonstruksi teks. Proses dekonstruksi teks dilakukan dengan memperbaiki teks, melengkapi, atau menambahkan isi teks yang sudah ada (Ramadania, 2016). Tahap akhir pada pembelajaran dengan menggunakan model pembelajaran berbasis teks yakni tahap joint construction the text. Pada tahap ini peserta didik sudah mulai bekerja dalam kelompok dan bimbingan guru sudah mulai berkurang, namun tetap memberikan feedback atas kerja peserta didik dalam kelompok.

Model pembelajaran berbasis teks yang dilaksanakan bersamaan dengan model pembelajaran kerja kelompoknya tentunya dapat meningkatkan efektifvtas belajar siswa. Hal ini dikarenakan pada model pembelajaran kerja kelompok siswa dapat melakukan sharing informasi bersama dengan anggota kelompoknya (Pingga, 2021). Pembelajaran menggunakan metode kerja kelompok dapat mengembangkan perilaku gotong royong dan demokratis. Kerja kelompok dapat memacu siswa aktif belajar, kerja kelompok tidak membosankan siswa melakukan kegiatan belajar (Miran \& Tampubolon, 2017). Beberapa penelitian yang telah dilakukan sebelumnya menyebutkan bahwa terdapat peningkatan keaktifan dan hasil belajar peserta didik pada mata pelajaran Bahasa Inggris melalui penerapan model pembelajaran berbasis teks (Rustini, 2021). Hasil penelitian lainnya juga menyebutkan bahwa metode pembelajaran berbasis teks sangat efektif digunakan dalam pembelajaran bahasa Indonesia. Melalui metode pembelajaran berbasis teks siswa dapat dengan mudah memahami serta merancang suatu karya tulis (Dewantara et al., 2019). Penelitian selanjutnya mengungkapkan bahwa metode kerja kelompok mampu meningkatkan motivasi belajar siswa, hal ini dikarenakan proses pembelajaran dengan menggunakan metode kerja kelompok mampu menciptakan suasana belajar yang menyenangkan serta tidak membuat jenuh siswa (Papasi, 2020). Hasil tersebut menunjukkan bahwa pada dasarnya penggunaan model pembelajaran berbasis teks dan kerja kelompok mampu meningkatkan kemampuan bahasa dan motivasi belajar siswa, sehingga sangat layak digunakan dalam proses pembelajaran. namun model pembelajaran berbasis teks dan kerja kelompok ini memiliki kekurangan yaitu dalam penerapannya membutuhkan waktu yang lama. Implikasi penelitian ini diharapkan dapat membantu guru dalam meningkatakan kemampuan kognitif siswa dengan menggunakan model pembelajaran berbasis teks dan kerja kelompok.

\section{SIMPULAN}

Penggunaan model pembelajaran berbasis teks dan kerja kelompok dapat meningkatkan keterampilan menulis teks peserta didik. Hal itu diketahui dari adanya peningkatan nilai rata-rata yang diperoleh peserta didik dari tahap prasiklus, siklus I, dan siklus II. Selain itu, respon peserta didik dalam pembelajaran menulis teks prosedur juga meningkat ketika guru menggunakan metode pembelajaran berbasis teks dan kerja kelompok dalam proses pembelajaran. Hal ini dapat dilihat berdasarkan kuesioner yang diisi oleh peserta didik. Hasil yang didapatkan dari respons peserta didik terhadap pelaksanaan tindakan menunjukkan respon positif dan sudah ada peningkatan respon pada setiap siklus. 


\section{DAFTAR RUJUKAN}

Adeninawaty, D., Soe'oed, R., \& Ridhani, A. (2018). Penerapan Model Pembelajaran Discovery Learning Strategi Think Talk Write dalam Meningkatkan Motivasi dan Hasil Belajar Menulis Teks Ulasan Kelas VIII SMP. Diglosia: Jurnal Kajian Bahasa, Sastra, Dan Pengajarannya, 1(2), 75-88. https://doi.org/10.30872/diglosia.v1i2.11.

Ati, A. P., Widiyarto, S., \& Suyana, N. (2018). Penerapan Metode Picture and Picture untuk Peningkatan Keterampilan Menulis Narasi pada Siswa Kelas VIII SMP Al Ihsan Dan SMP Tashfia Kota Bekasi. Adimas : Jurnal Pengabdian Kepada Masyarakat, 2(1), 30. https://doi.org/10.24269/adi.v2i1.887.

Darlan, Chairil, \& Elly. (2021). Meningkatkan Keaktifan dan Hasil Belajar Siswa melalui Penerapan Pembelajaran Berbasis Teks pada Mata Pelajaran Bahasa Inggris Kelas VII B SMP Negeri 1 Majene Sulawesi Barat. Jurnal Pemikiran Dan Pengembangan Pembelajaran Meningkatkan, 3(2), 1-23. http://www.ejournal-jp3.com/index.php/Pendidikan/article/view/142.

Devi, P. C. (2018). Pengembangan Bahan Ajar Menulis Teks Prosedur Kompleks dengan Model Pembelajaran Discovery Learning Menggunakan Media Audio Visual (Video) Di Kelas XI SMA Negeri 1 Samarinda. Diglosia: Jurnal Kajian Bahasa, Sastra, Dan Pengajarannya, 1(2), 101-114. https://doi.org/10.30872/diglosia.v1i2.13.

Dewantara, A. A. N. B. J., Sutama, I. M., \& Wisudariani, N. M. R. (2019). Pembelajaran Bahasa Indonesia Berbasis Teks di SMA Negeri 1 Singaraja. Jurnal Pendidikan Bahasa Dan Sastra Indonesia Undiksha, 9(2). https://doi.org/10.23887/jjpbs.v9i2.20462.

Engliana, E., Dwiastuty, N., Miranti, I., \& Nurjanah, N. (2020). Penguatan Pendidikan Karakter melalui Cerita Rakyat pada Pelajaran Bahasa Inggris di Perguruan Tinggi. Jurnal Pendidikan Karakter, 10(1). https://doi.org/10.21831/jpk.v10i1.28814.

Estrini, D. (2021). Penerapan Genre Based Approach (Gba) dalam Pembelajaran Bahasa Inggris SMPN 1 Panimbang. Teacher: Jurnal Inovasi Karya Ilmiah Guru, 1(1), 96-101. https://doi.org/10.51878/teacher.v1i1.544.

Faiza, F. S., \& Erowati, R. (2021). Tingkat Kemampuan Berbicara Pemelajar BIPA (Bahasa Indonesia Penutur Asing) Tingkat Pemula Menggunakan Tes Teks Deskripsi. Jurnal Bahasa, Sastra Dan Pengajarannya, 2(2). https://doi.org/10.22515/tabasa.v2i2.3883.

Hendrawan, D. N., \& Indihadi, D. (2019). Implementasi Proses Menulis pada Keterampilan Menulis Teks Deskripsi Tokoh Cerita Fiksi. PEDADIDAKTIKA: Jurnal Ilmiah Pendidikan Guru Sekolah Dasar, 6(1), 47-57. https://ejournal.upi.edu/index.php/pedadidaktika/article/view/12689/8852.

Henny, A., \& Fatmasari, E. (2020). Peningkatan Keterampilan Menulis Bahasa Inggris dengan Menggunakan Metode Pembelajaran Kooperatif Melalui Permainan Chain Word Flag. Jurnal Studi Guru Dan Pembelajaran, 3(2). https://doi.org/10.30605/jsgp.3.2.2020.312.

Hikmatin, T. (2020). Pengaruh Minat Baca dan Penguasaan Kosakata terhadap Kemampuan Menulis Cerita Pendek. Diskursus: Jurnal Pendidikan Bahasa Indonesia, 1(03), 286. https://doi.org/10.30998/diskursus.v1i03.6696.

Kiuk, Suputra, \& Adnyani. (2021). Upaya Meningkatkan Kemampuan Menulis Melalui Strategi Please. Indonesian Gender and Society Journal, 2(1), 10. https://doi.org/10.23887/igsj.v2i1.39207.

Koswara. (2021). Meningkatan Keterampilan Menulis Deskripsi Bahasa Inggris melalui Pembelajaran Berbasis Projek pada Siswa SMP. JIRA: Jurnal Inovasi Dan Riset Akademik, 2(7), 1008-1015. https://doi.org/10.47387/jira.v2i7.186.

Mabruri, Z. K. (2021). Pengelolaan Bahasa untuk Pembelajaran di Indonesia. NATURALISTIC : Jurnal Kajian

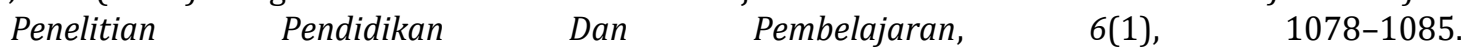
https://doi.org/10.35568/naturalistic.v6i1.1609.

Miran, M. A., \& Tampubolon, B. (2017). Peningkatan Hasil Belajar IPS Menggunakan Metode Kerja Kelompok Kelas V SDN 09 Bengkayang. Jurnal Pendidikan Dan Pembelajaran Untan, 7(3), 1-16. https://jurnal.untan.ac.id/index.php/jpdpb/article/view/24635/75676576162.

Munggaraning, S., \& Westhisi. (2019). Metode Fonik dalam Pembelajaran Membaca Permulaan Bahasa Inggris Anak Usia Dini. Tunas Siliwangi: Jurnal Program Studi Pendidikan Guru Paud, 5(1). https://doi.org/10.22460/ts.v5i1p29-43.1271.

Musa, M. Q. (2019). Pembelajaran Menulis Bahasa Inggris Menggunakan Edmodo. Tawazun: Jurnal Pendidikan Islam, 10(1), 100. https://doi.org/10.32832/tawazun.v10i1.1157.

Narasintawati, L. S., Huraiyah, \& Aliyah, S. (2020). Penerapan Genre Based Approach (GBA) dalam Pembelajaran Bahasa Inggris SMP. Indonesian Journal of Teacher Education, 1(2), 1-9. https://journal.publication-center.com/index.php/ijte/article/view/110/64.

Papasi, J. (2020). Meningkatkan Motivasi Belajar Siswa dengan Menggunakan Metode Kerja Kelompok pada Mata Pelajaran Pendidikan Agama Kristen di SMP Negeri I Totikum Sulawesi Tengah. Jurnal Paedagogy, 7(4), 339. https://doi.org/10.33394/jp.v7i4.2879. 
Pingga, Y. S. (2021). Model Pembelajaran Kooperatif dalam Meningkatkan Minat Belajar Pendidikan Agama Kristen. Harati: Jurnal Pendidikan Kristen, 1(2), 201-222. https://doi.org/10.54170/harati.v1i2.78.

Prakoso, A. R., Seriardana, P., \& Adnyani, L. D. S. (2021). Implementasi Genre Based Approach untuk Meningkatkan Keterampilan Menulis Explanation Text. Indonesian Gender and Society Journal, 2(1), 1. https://doi.org/10.23887/igsj.v2i1.39206.

Puwerman. (2021). Upaya Peningkatan Kompetensi Belajar Bahasa Indonesia melalui Metode Diskusi Kelompok Menggunakan Point System bagi Siswa Kelas X SMAN 16 Tebo. Secondary: Jurnal Inovasi Pendidikan Menengah, 1(4), 329-335. https://doi.org/10.51878/secondary.v1i4.633.

Rahma, A. F., Atmazaki, \& Abdurahman. (2018). Pembelajaran Bahasa Indonesia Berbasis Teks di SMP Negeri Kabupaten Padang Pariaman. Jurnal Ilmiah Kebudayaan Sintesis, 11(1), 1-11. https: //doi.org/10.24036/100704-019883.

Ramadania, F. (2016). Konsep Bahasa Berbasis Teks pada Buku Ajar Kurikulum 2013. STILISTIKA: Jurnal Bahasa, Sastra, Dan Pengajarannya, 1(2). https://doi.org/10.33654/sti.v1i2.372.

Ratnawati. (2020). Penerapan Model Pembelajaran Berbasis Proyek pada Pembuatan Strip Komik untuk Meningkatkan Kemampuan Menulis Bahasa Inggris. Indonesian Journal of Educational Development, 1(3), 481-495. https://doi.org/10.5281/zenodo.4286867.

Rustini, M. (2021). Peningkatan Keaktifan dan Hasil Belajar Siswa melalui Penerapan Model Pembelajaran berbasis Teks pada Mata Pelajaran Bahasa Inggris Kelas VIIA. Jurnalwawasan Pengembangan Pendidikan, 9(2). http://ejournal.undaris.ac.id/index.php/waspada/article/view/276/204.

Sijabat, R. I., \& Dinar, F. (2019). Pengaruh Metode Kerja Kelompok terhadap Hasil Belajar Keselamatan Kerja Siswa SMK Negeri 3 Pematangsiantar. Jurnal Keluarga Sehat Sejahtera, 17(2). https://doi.org/10.24114/jkss.v17i2.16470.

Sobandi, H. R. (2020). Peningkatan Keaktifan dan Hasil Belajar Bahasa Inggris Kompetensi Menulis dalam Teks Prosedur melalui Model Pembelajaran Make A Match Siswa Kelas IX MTs Negeri 5 Kuningan Tahun Pelajaran 2019/2020. Fon: Jurnal Pendidikan Bahasa Dan Sastra Indonesia, 16(2), 116. https://doi.org/10.25134/fjpbsi.v16i2.3506.

Soleh, D. (2021). Penggunaan Model Pembelajaran Project Based Learning melalui Google Classroom dalam Pembelajaran Menulis Teks Prosedur. Ideguru: Jurnal Karya Ilmiah Guru, 6(2), 137-143. https://doi.org/10.51169/ideguru.v6i2.239.

Sulissusiawan, A. (2019). Pelaksanaan Pembelajaran Teks Eksposisi pada Siswa SMA Negeri 1 Subah Kabupaten Sambas Tahun Ajaran 2018/2019. Jurnal Pendidikan Dan Pengajaran, 8(9). https://jurnal.untan.ac.id/index.php/jpdpb/article/view/36117/75676583204.

Sulistyowati, W. (2018). Peningkatan Hasil Belajar Berbicara Teks Prosedur elalui Metode Presentasi Power Point Mata Pelajaran Bahasa Inggris pada Peserta Didik Kelas IX G Semester 1Tahun Pelajaran 2017 / 2018 SMP Negeri 1 Tugu. Journal of English Language Teaching, Linguistics and Literature, 2(1), 79-100. https://doi.org/10.29100/bright.v2i1.741.

Suryani, L. (2021). Peningkatan Hasil Belajar Menulis Teks Prosedur melalui Metode Demonstrasi Kelas IX A SMP Negeri 1 Pogalan. Language : Jurnal Inovasi Pendidikan Bahasa Dan Sastra, 1(1), 115-122. https://doi.org/10.51878/language.v1i1.483.

Trisnadewi, K., Brahma, A. A. G. R. W., \& Monny, M. O. E. (2020). Pemanfaatan Cartoon Story Maker, Sebuah Teknologi Komik Digital sebagai Media Pembelajaran Menulis Bahasa Inggris. Paedagoria : Jurnal Kajian, Penelitian Dan Pengembangan Kependidikan, 11(2), 179-187. https://doi.org/10.31764/paedagoria.v11i2.2487.

Uddin, A., \& Oktaviarini, N. (2019). Analisis Kemampuan Bercerita Siswa dengan Metode Kerja Kelompok Kecil Siswa Kelas III Tema 6 Energi dan Perubahannya di SD Negeri 02 Penjor Kecamatan Pagerwojo Kabupaten Tulungagung Tahun Ajaran 2018/2019. JEMARI (Jurnal Edukasi Madrasah Ibtidaiyah), 1(2), 41-47. https://doi.org/10.30599/jemari.v1i2.510.

Utama, S. (2019). Menulis Teks Berbentuk Procedure melalui Model Pembelajaran Make a Match. SAP (Susunan Artikel Pendidikan), 4(1). https://doi.org/10.30998/sap.v4i1.4113.

Utami, R. (2021). Peningkatan Hasil Belajar Membaca Teks Procedure melalui Media Quizziz Pada Peserta Didik Kelas IXE Semesrter I SMP Negeri 1 Pekalongan Tahun Pelajaran 2021/2022. Jurnal Mutiara Pendidikan, 6(2). https://doi.org/10.51544/mutiara\%20pendidik.v6i2.2383.

Wahyudin, A. Y., Jepri, D., Simamora, M. W., Pratiwi, I. W., \& Rina, A. (2020). Penggunaan Komik Digital Toondoo dalam Pembelajaran Bahasa Inggris Tingkat Sekolah Menengah. Journal of Social Sciences and Technology for Community Service (JSSTCS), 1(1), 1. https://doi.org/10.33365/jta.v1i1.673. 